\title{
Job mobility and hours of work: the effect of Dutch legislation
}

Citation for published version (APA):

Fouarge, D., \& Baaijens, F. P. (2009). Job mobility and hours of work: the effect of Dutch legislation. Researchcentrum voor Onderwijs en Arbeidsmarkt, Faculteit der Economische Wetenschappen. ROA Research Memoranda No. 4 https://doi.org/10.26481/umaror.2009004

Document status and date:

Published: 01/01/2009

DOI:

10.26481/umaror.2009004

Document Version:

Publisher's PDF, also known as Version of record

\section{Please check the document version of this publication:}

- A submitted manuscript is the version of the article upon submission and before peer-review. There can be important differences between the submitted version and the official published version of record.

People interested in the research are advised to contact the author for the final version of the publication, or visit the DOI to the publisher's website.

- The final author version and the galley proof are versions of the publication after peer review.

- The final published version features the final layout of the paper including the volume, issue and page numbers.

Link to publication

\footnotetext{
General rights rights.

- You may freely distribute the URL identifying the publication in the public portal. please follow below link for the End User Agreement:

www.umlib.nl/taverne-license

Take down policy

If you believe that this document breaches copyright please contact us at:

repository@maastrichtuniversity.nl

providing details and we will investigate your claim.
}

Copyright and moral rights for the publications made accessible in the public portal are retained by the authors and/or other copyright owners and it is a condition of accessing publications that users recognise and abide by the legal requirements associated with these

- Users may download and print one copy of any publication from the public portal for the purpose of private study or research.

- You may not further distribute the material or use it for any profit-making activity or commercial gain

If the publication is distributed under the terms of Article $25 \mathrm{fa}$ of the Dutch Copyright Act, indicated by the "Taverne" license above, 


\section{Job mobility and hours of work: the effect of Dutch legislation}

Didier Fouarge

Christine Baaijens

ROA-RM-2009/4

March 2009

Research Centre for Education

and the Labour Market

P.O. Box 616

6200 MD Maastricht

The Netherlands

E-mail: $\quad$ secretary@roa.unimaas.nl

Internet: $\quad$ www.roa.unimaas.nl

Maastricht University

Faculty of Economics and Business Administration 
The ROA Research Memorandum Series was created in order to make research results available for discussion, before those results are submitted for publication in journals.

Sec09.017.pdf 
ROA-RM-2009/4 》 http://www.roa.unimaas.nl/resmem.htm

\section{Abstract}

\section{Job mobility and hours of work: the effect of Dutch legislation}

Previous research has pointed to the existence of hours constraints on the labour market: not all employees' preferences with respect to the length of the working week seem to be fulfilled, and changes in the number of working hours often coincide with job mobility. In this paper, we test whether or not a recently introduced Dutch legislation providing employees with the right to adjust working hours within their job has reduced the correlation between changes in working hours and job mobility. We do this by implementing a difference-in-differences methodology to the job and hours mobility behaviour of Dutch workers prior and after the introduction of the new law. We find no evidence suggesting that this is indeed the case, regardless of gender.

JEL Classification: J22, J62, J83, C35

Key words: labour market transition, working time legislation, working time, longitudinal data, The Netherlands

Didier Fouarge

ROA / Maastricht University

PO Box 616

6200 MD Maastricht

The Netherlands

E-mail: d.fouarge@roa.unimaas.nl
Christine Baaijens

Déhora Consultancygroup

PO Box 7850

1008 AB Amsterdam

The Netherlands

E-mail: c.baaijens@dehora.nl 



\section{Introduction}

A large amount of literature suggests that hour constraints are important determinants of job mobility: workers who are constrained in their labour supply are more likely to change job or to leave the labour market. Such evidence is discussed by Böheim and Taylor (2004) and Gielen (2009) for the UK, by Altonji and Paxson (1992) and Martinez-Granado (2005) for the US and by Euwals (2001) for the Netherlands. In this paper, we contribute to this literature by investigating whether or not legislation can contribute to the removal of working hour constraints.

The legislation we refer to is the Adjustment of Working Hours Act that was introduced in July 2000 by the Dutch government. The main objective of this Act is to facilitate employees' adjustment of working hours: employees are given the right to adapt the length of their working week within their current job (see Section 2 for details). Such piece of legislation is not unique to the Netherlands since a similar Act also exists in Germany and, to a lesser extent, in the UK. This makes the Dutch results interesting to the international community. It is of particular interest as such new working hours policy could help mothers in the combination of paid employment and care (Dex and Joshi, 1999). The effect of the Adjustment of Working Hours Act is assessed using the difference-indifferences methodology. We compare mobility patterns of workers in small firms - for which the obligations in the Act do not hold -and large firms before and after the introduction of the Act. Furthermore, we also compare the difference in mobility patterns of employees who are satisfied with their current number of working hours with that of those who are dissatisfied, before and after the introduction of the Act.

Our second contribution to the literature is that, contrary to previous research, we take the view that the choice for a job and the choice for a particular number of working hours are taking place simultaneously. Workers do not just 'choose' a number of working hours and then a job that goes with it as is often assumed, but they consider job-hour packages. This is because jobs tend to come with a specific number of working hours. Hence, we assume that a utility maximising employee can choose to remain in the same job with the same number of working hours, to change working hours within the same job, to change job but 
to keep the same number of working hours, to change both job and working hours or to withdraw from the labour market altogether. We model this job-hours choice set using a multinomial logit model. The model is estimated on longitudinal data of Dutch employees for the period 1986-2006.

Our main finding is that the association between changes in working hours and job mobility has not been altered by the aforementioned Act. We conclude that this type of legislation has little effect on removing hour constraints and argue why this is the case.

The paper is organised as follows. In Section 2 we give a sketch of the Dutch labour market and its institutions. In Section 3 we review the literature on working hour preferences and job mobility. The empirical model and the data used for estimation are discussed in Section 4. The descriptive results and the model estimates are presented in Section 5. In Section 6 we discuss our main findings.

\section{The Dutch labour market in international perspective}

\subsection{High rate of part-time employment}

Since the beginning of the 1970s, most European Union (EU) countries have seen a significant growth in the proportion of part-timers in the total labour force. However, in no other country in the EU is part-time employment as widespread as it is in the Netherlands. According to Eurostat, $46.8 \%$ of the workforce was employed part-time in the Netherlands in 2007. The next highest rate is found in Germany (26\%), closely followed by the UK (25.2\%), Sweden (25\%), and Denmark $(24.1 \%)$. Although part-time work remains a predominant feature of female employment, a large share of the Dutch male labour force is working parttime, compared to other countries. The large share of part-timers in the Netherlands today is the result of a combination of labour demand and supply factors. On the demand side, the advance in part-time employment can be explained by a change in attitude among employers who started to see its advantages in a context of extending operating hours and a growing service sector (Delsen et al., 2007). On the supply side the entry of married women in the labour force, and the increasing participation rate of mothers has also contributed greatly to the increase in part-time employment (Portegijs and Keuzenkamp, 2008). 
Dutch labour market policy has contributed to the normalisation of part-time employment by introducing various measures to improve the legal position of parttimers in the last decades. In the Netherlands, jobs with fewer than 35 hours per week are considered to be part-time jobs. In 1993, thresholds that related to the number of working hours were removed from entitlements to the statutory minimum wage and the minimum holiday allowance. Legislation in 1996 elaborated on the subject, by prohibiting discrimination between employees based upon the number of working hours. This piece of legislation awards part-time employees an explicit right to equal treatment - pro rata - in areas negotiated by the social partners, such as wages, holiday pay and entitlements, bonuses and training. As a result, today, part-timers and full-timers enjoy similar conditions of employment in the Netherlands. Moreover, in many branches of industry - such as healthcare, the public sector, education and services - part-time work has become a normal and accepted phenomenon. In this respect the Dutch situation sharply contrasts to the situation in other countries, where part-time employment is often a form of marginal employment (Visser, 2002: 25). ${ }^{1}$

\subsection{A right to change the number of working hours}

With the legal position of part-timers being secured, the Dutch government turned its attention towards increasing participation through part-time employment in the 1990s. One of the reasons for this is that part-time employment is seen as a means for both men and women to combine work and caring activities. It is in this context that the Adjustment of Working Hours Act (Wet Aanpassing Arbeidsduur) came into force in July 2000. According to the Act, employees have the right to request an upward or downward adjustment of the number of working hours in their current job. Any employee who has been employed with his or her current employer for more than one year can make use of this legal right once every two years. Essentially, employers have to honour such requests unless precluded by pressing conflicting business interests. Although this does not imply that all requests have to be honoured, it does imply that employers have to justify refusals. Employees, however, are under no obligation to motivate their request. This

1. Nevertheless, even in the Netherlands, part-timers seem to have fewer career prospects and fewer chances to enter management jobs than full-timers (Fouarge and Muffels, 2009). 
difference in treatment of employers and employees shows that the legislator has taken side with workers in their effort to realise their desired number of working hours. In case the employer refuses to honour the employee's request, the latter can turn to the judge. The available jurisprudence suggests that once an employee steps to court, the judge is more likely to pass a judgement in favour of the employee than in favour of the employer (Carmonier, 2003; Veldman, 2003). The Act is equally applicable to employees in the market and the public sector. Note, however, that the Act excludes organisations with less than ten employees, which are expected to develop their own arrangement. This differential treatment between small and large firms will be used to identify the effect of the law in our empirical analysis.

Such legislation is not unique to the Netherlands, which makes the study of its effects of interest to the international community. Within the European Union, comparable laws exist in Germany and the UK. The German Act on Part-time Work and Fixed-Term Contracts (Gesetz über Teilzeitarbeit und befristete Arbeitsverträge) came into force in January 2001. The law introduced the right to switch from full-time to part-time, but the question whether or not this right is reversible is the subject of ongoing debate (Schmidt, 2001; Jacobs and Schmidt, 2001; Burri et al., 2003). In the UK, parents of young children may request flexible working hours from their employer, but the scope of this right is less wide and conditions of entitlement are more rigid than in the Netherlands (EIRO, 2003).

We conclude that there is a great amount of working hour flexibility in the Netherlands for three reasons. Firstly, the large share of part-time employment suggests that part-time jobs are readily available. Secondly, the legal position of part-time workers is well secured, preventing part-time jobs from being marginalised jobs. Finally, the Adjustment of Working Hours Act has removed formal barriers to transitions from full- to part-time employment and back.

\section{Labour supply preferences and hours restrictions}

Working hour preferences and working hour changes have been the subject of much research already. In their study of hour constraints Kahn and Lang (1992), for example, conclude that a substantial proportion of working males in the US 
work fewer hours than they would like to, and they investigate possible explanations for this. The situation in Europe is somewhat different because there is a stronger preference to work fewer hours (Freeman and Schettkat, 2005). According to a study covering $15 \mathrm{EU}$ member states and Norway, half of the workforce surveyed preferred to work fewer hours and 11 per cent preferred to work more hours (Bielenski et al., 2002: 43). However, almost two thirds of fulltimers assume that their current employer would not agree to let them work parttime - ranging from 71 per cent in Austria to 44 per cent in Finland - while almost half of them say that working part-time would harm their career prospects ranging from 55 per cent in Germany to 31 per cent in Denmark (Bielenski et al., 2002: 57).

In their seminal contributions, Altonji and Paxson $(1986,1988,1992)$ have studied adjustment of working hours of married women in the US. They distinguish between women who stay in their job and women who change employer. The authors conclude - using the US Panel Study of Income Dynamics - that working hours of married women are two to four times more variable when changing employer than when staying in the same job. Based upon the US National Longitudinal Survey of Youth, Martinez-Granado (2005) finds that for prime aged males the variance of the change in hours is more than six times higher across jobs (defined as a change of employer) than within jobs. Both findings suggest that male and female employees in the US have difficulties adjusting working hours without changing employer. In addition, Böheim and Taylor (2004) find - using the British Household Panel Survey - that job changers in Great Britain are better able to adjust working hours in line with their preferences than those who stay in the same job. For the Netherlands, Euwals (2001) - using the Dutch Socio-Economic Panel covering the years prior to the introduction of the Adjustment of Working Hours Act - finds that flexibility of working hours within jobs is low among female employees. As a result, women who stay with the same employer have a much smaller chance of adjusting their working hours than women who change jobs.

Why are employees reluctant to request fewer or more working hours? Employees (especially male employees) think that their employer or their job are important obstacles in realising a preference for working a different number of working hours (Fouarge and Baaijens, 2006). They seem to fear that their 
employer does not approve or to think that it is not possible in their job, although this may not objectively be the case. For employees in management positions it is often the norm to work full-time, which might form a barrier for them to request a reduction of the working week. Being employed full-time is also often seen as an indication of loyalty to the firm (Landers et al., 1996). It is possible that both employees and employers have such perceptions.

Although job mobility is not a bad thing in itself, job mobility that is solely induced by dissatisfaction with the number of working hours - rather than dissatisfaction with the job itself, or differences in productivity across jobs - is inefficient for at least three reasons. Firstly, job mobility involves search costs for the employee. Secondly, it involves search costs for the firm to replace the departing employee. Thirdly, it results in the loss of firm specific human capital.

If it is indeed the case that workers who wish to adapt their labour supply are more inclined to change job, then a piece of legislation that facilitates hours changes within the job should be beneficial to the economy. The new Dutch Adjustment of Working Hours Act is an interesting natural experiment for testing this. This, however, has never been done before.

\section{Data and empirical model}

The findings discussed in Section 3 point to the existence of hour constraints - or at least perceived hour constraints - on the labour market, which result in a strong association between hours change and job mobility: when an adjustment of hours takes place, it generally involves a job change. In the remainder of this paper we analyse this relationship between job mobility and changes in working hours in the context of the Dutch 'part-time economy', and we examine whether or not legislation does remove such restrictions.

\subsection{Data: OSA Labour Supply Panel}

To study the process of working hour adjustments and job mobility, we use longitudinal information from the OSA Labour Supply Panel. This is a panel of Dutch persons that is representative for the population aged 16 to 64. As of 1986, data are collected every other year among some 4,500 persons in more than 2,000 
households. We use eleven waves of the panel covering the period 1986-2006. We selected employees aged 18 to 55 . We exclude self-employed and young people who are employed but engaged in full time education. The data is organised as a person-period file, and the standard errors of our estimates are corrected for intragroup correlation. The estimation sample consists of some 3,800 working males and 2,900 working females.

The data include a wide range of information on demographic characteristics at the level of the individual and the household, human capital indicators, socio-economic characteristics and job characteristics. The data also include information on contractual and preferred working hours and job mobility. Contractual working hours refer to the number of working hours that employer and employee have agreed upon in the labour contract. ${ }^{2}$ The preference for working hours is assessed by asking employees for their preferred number of working hours. A comparison of contractual and preferred working hours reveals whether or not employees are satisfied with the length of their working week. From 2000 on, however, respondents are asked directly whether they want to work more or fewer hours. ${ }^{3}$ This change in the questionnaire has had only a minor effect on the pattern of answers given, leading only to a sharper decrease in the proportion of employees stating they would prefer to work more hours, compared to other national sources (Beckers and van der Valk, 2005). This, however, is of no particular concern for the current study. Given the biennial nature of our data, we measure job mobility as a job change with the same employer or a change of employer between $t$ and $t+2$.

\subsection{Modelling hours changes and job mobility}

The standard neo-classical model of labour supply predicts that workers develop preferences for the number of hours they want to work and adapt their labour supply in accordance with those preferences. However, job offers tend to come with a set number of working hours. Therefore it is more realistic to assume that

2. This excludes overtime hours because the Adjustment of Working Hours Act only applies to contractual working hours. Overtime is controlled for in the empirical model.

3. It is important to note that, in all years, respondents had to assume that their hourly wage and the labour supply of other household members remained unchanged when reporting their preferred number of working hours. It was made explicit that working fewer (more) hours implied a reduction (increase) in income. 
workers search for job-hours combinations that best fit their preferences. For example, a dissatisfaction resulting from working more hours than the preferred number of working hours can be offset by the fact that the job is interesting or stimulating. It is also possible that the amenities of a particular job are compensated by lower levels of working hours.

The fact that we focus on the effects of legislation on working time changes is also a reason why we look at job-hour packages. Indeed, the Dutch Adjustment of Working Hours Act is not only expected to facilitate changes in the working hours, but also to reduce job mobility - in particular withdrawal from the labour market -resulting from dissatisfaction with respect to the number of working hours.

The labour market position of an individual $i$ at time $t$ is characterised by a given number of working hours in a particular job. In this paper, we are interested in the change in this labour market position - change of hours and/or change of job - between $t$ and $t+2$. A change of hours can mean either an increase or a decrease in the number of working hours (the Dutch Act aims at facilitating both). ${ }^{4}$ Henceforth, at each time period, a utility maximising employee can choose:

1) to remain in the same job with the same number of working hours (no job mobility/no change of hours);

2) to change job but to keep the same number of working hours (job mobility/no change of hours);

3) to change working hours within the same job (no job mobility/change of hours);

4) to change both job and working hours (job mobility/change of hours);

5) to withdraw from the labour market altogether (exit labour market).

4. In the model, a change in the number of working hours is defined as a change of at least 4 hours. This is not only done in order to account for small measurement errors, but also because it is assumed that small adjustments in the working hours are easily negotiable with the employer. Furthermore, this prevents collective working time reduction - the gradual reduction of the standard working week from 40 to 36 hours in the paste decades - to affect our results. However, replication of the estimation without this restriction shows that it does not affect our findings in any significant way. 
Table 1

Variables used in model and sample statistics

\begin{tabular}{|c|c|c|}
\hline & Mean & $\begin{array}{l}\text { Standard } \\
\text { deviation }\end{array}$ \\
\hline Female (1 if yes) & 0.407 & 0.491 \\
\hline Age & 38.057 & 9.235 \\
\hline Household type: couple, no child jonger than 6 y.o. (1 if yes) & 0.590 & 0.492 \\
\hline Household type: couple with child younger than 6 y.o. ( 1 if yes) & 0.237 & 0.426 \\
\hline Household type: single (1 if yes) & 0.173 & 0.378 \\
\hline Educational level: lower education (1 if yes) & 0.376 & 0.484 \\
\hline Educational level: secondary education ( 1 if yes) & 0.371 & 0.483 \\
\hline Educational level: high education/university ( 1 if yes) & 0.252 & 0.434 \\
\hline Number of hours worked by partner ( 0 if no partner) & 21.316 & 17.473 \\
\hline Hourly wage in constant 2006 prices (in logarithm) & 2.017 & 0.435 \\
\hline \multicolumn{3}{|l|}{ Part-time job (working less than 35 hours per week) } \\
\hline (1 if yes) & 0.342 & 0.475 \\
\hline Does overtime work ( 1 if yes) & 0.397 & 0.489 \\
\hline Permanent contract ( 1 if yes) & 0.892 & 0.310 \\
\hline Managerial job (1 if yes) & 0.647 & 1.191 \\
\hline Heavy duty ( 1 if yes) & 0.337 & 0.473 \\
\hline Dissatisfied with the job ( 1 if yes) & 0.091 & 0.287 \\
\hline Dissatisfied with number of hours ( 1 if yes) & 0.279 & 0.449 \\
\hline Sector: Industry and energy ( 1 if yes) & 0.161 & 0.368 \\
\hline Sector: Agriculture (1 if yes) & 0.013 & 0.113 \\
\hline Sector: Construction ( 1 if yes) & 0.062 & 0.241 \\
\hline Sector: Commerce, catering ( 1 if yes) & 0.147 & 0.354 \\
\hline Sector: Transport ( 1 if yes) & 0.066 & 0.249 \\
\hline Sector: Financial business services ( 1 if yes) & 0.131 & 0.337 \\
\hline Sector: Other services ( 1 if yes) & 0.050 & 0.218 \\
\hline Sector: Public sector ( 1 if yes) & 0.109 & 0.311 \\
\hline Sector: Education ( 1 if yes) & 0.091 & 0.287 \\
\hline Sector: Healthcare (1 if yes) & 0.171 & 0.376 \\
\hline Firm size: $1-9$ employees ( 1 if yes) & 0.132 & 0.339 \\
\hline Firm size: $10-99$ employees ( 1 if yes) & 0.414 & 0.493 \\
\hline Firm size: >99 employees (1 if yes) & 0.454 & 0.498 \\
\hline Time period: $1986-1994$ (1 if yes) & 0.413 & 0.492 \\
\hline Time period: $1994-2000$ ( 1 if yes) & 0.266 & 0.442 \\
\hline Time period: $2000-2006$ ( 1 if yes) & 0.321 & 0.467 \\
\hline Regional unemployment rate & 6.665 & 2.015 \\
\hline
\end{tabular}

We model this job-hours choice set using a multinomial logit model, where remaining in the same job with the same number of hours is treated as the reference. A similar modeling strategy is used by Gielen (2009). In the model, we include a number of control variables pertaining to individual characteristics (age, 
educational level), household characteristics (household type, labour supply of

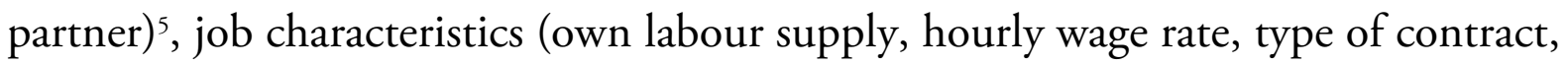
sector of activity, firm size and dummy variables for managers, work involving heavy duty, overtime and dissatisfaction with work), and preference for working more of fewer hours. Table 1 reports summary statistics for these variables. The model is estimated for males and females separately. The reason for this is that the legislation tested here has a clear emancipatory component which is likely to have a larger effect on females' labour market behaviour than of that of males.

\subsection{Identifying the effect of legislation: difference-in-differences estimator}

Our test of the effect of the Adjustment of Working Hours Act consists of a pre/post evaluation using the difference-in-differences methodology. Therefore, in addition to the aforementioned control variables, the model includes a number of time dummies. They distinguish the pre-Act period (prior to 2000) from the postAct period (2000-2006). Within the pre-Act period, we make a distinction between the period 1994-2000 and the years before because the second half of the nineties was marked by a sharp increase in the labour participation rate of females. The period 1994-2000 is used as reference period. To ensure our pre/post comparison is not affected by structural changes in the economy, the unemployment rate at the level of the twelve Dutch provinces is included among the regressors in order to catch business cycle effects. This implies that the time dummies capture changes that are not related to the business cycle.

Because the new Act does not apply to small firms, employees in small firms can be used as a control group in this study. We implement a difference-indifferences estimator by introducing interactions between the period effects and the firm size. These interaction terms indicate whether or not the association between mobility and firm size has changed over the years. While mobility in small firms could be different from mobility in large firms, the assumption we make here is that this difference would have remained constant over time had the Act not come into force. Under the assumption that the Act has had an effect on employees'

5. Although one could argue that partners labour supply is jointly determined, here, the labour supply of the partner is merely included as an additional control variable. 
mobility patterns, we expect this cross-term to be positive for large firms for the 'no job mobility/change of hours' mobility. This would show that, compared to employees in small firms, employees in large firms find it easier to change their hours while remaining in their job after the law changed.

The covariates also include a dummy for workers who are dissatisfied with their actual number of working hours: they would like to either work more or fewer hours. ${ }^{6}$ Here again, we implement a difference-in-differences estimator by introducing interactions between period effect and dissatisfaction with the number of working hours. Under the assumption that the Act has had an effect on mobility, we would expect that, compared to workers who are satisfied with their working hours, dissatisfied employees more easily adapt their hours without having to change job after the introduction of the Act. Hence we expect a positive sign for the coefficient indicating dissatisfaction in the post-Act period. Furthermore, we expect that dissatisfied workers less often change their working hours and their job at the same time in the post-Act period. Finally, as it has been shown that employees who are dissatisfied with their hours are more likely to withdraw from the labour market (Böheim and Taylor, 2004), we expect this to be less the case in the post-Act period. ${ }^{?}$

\section{Changes in working hours and job mobility}

\subsection{Descriptive findings}

The patterns of hours mobility and job mobility between $t$ and $t+2$ for the 19862006 period are depicted in Figure 1. The pattern of job mobility depicted in the figure follows the Dutch economy quite closely, with lower levels of job mobility in the periods 1992-1994 and 2002-2004 - both economic downturns - and increasing mobility in the years that followed. Flexibility in the length of the working week seems to follow this same pattern, with a two-year delay.

6. The difference between preferred and actual number of hours is at least 4 hours.

7. Attrition, which amounts to some $15 \%$ of the cases on a yearly basis, is in no way related to the variables of interest here such as the firm size or working time preferences. 


\section{Figure 1}

Percentage of workers who changed job and percentage of workers who changed hours between $\mathrm{t}$ and $\mathrm{t}+2$.

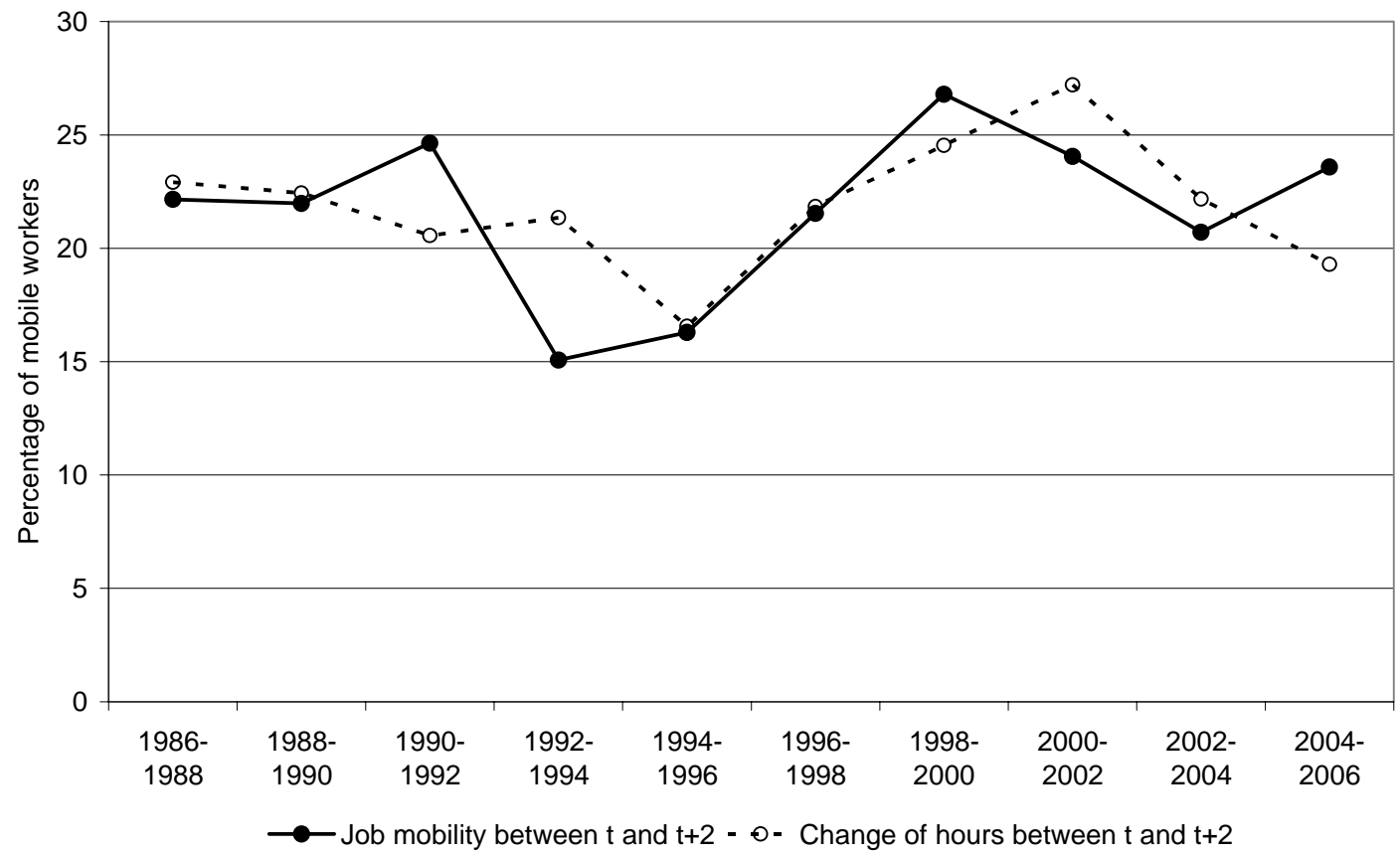

Table 2 reports the job mobility-hours change patterns (as discussed in Section 4) for the pre and the post-Act periods. From the table it appears that changes of working hours within the job have become more frequent over the years. However, job changes involving a change in the length of the working week have not become less frequent. Finally, it can be noted that the percentage of prime aged workers exiting the labour market has decreased.

\section{Table 2}

Hours and job mobility patterns of Dutch employees, percentages, 1986-2006

\begin{tabular}{lccc}
\hline & $1986-1994$ & $1994-2000$ & $2000-2006$ \\
\hline No job mobility / no change of hours $\left.{ }^{1}\right)$ & 57.9 & 60.6 & 58.0 \\
Job mobility / no change of hours $\left.{ }^{1}\right)$ & 19.6 & 16.8 & 17.3 \\
No job mobility / change of hours & 7.8 & 9.0 & 12.2 \\
Job mobility / change of hours & 7.7 & 8.0 & 8.2 \\
Exit from labour market & 7.1 & 5.7 & 4.2 \\
\hline Total & 100 & 100 & 100 \\
& $(\mathrm{n}=7,591)$ & $(\mathrm{n}=4,844)$ & $(\mathrm{n}=5,561)$ \\
\hline
\end{tabular}

${ }^{1)}$ No change or change is less than 4 hours. 
In Table 3, the mobility patterns are depicted for employees working in small firms compared to employees working in medium and large sized firms. In the table the patterns in the pre-Act period (1994-2000) are compared to those in the post-Act period (2000-2006). The pre/post difference-in-differences in mobility patterns are computed taking employees in small firms as the reference. What the table shows is that employees in large firms are more likely to stay in the same job with the same number of hours, and that the relative difference compared to employees in small firms has increased between the two time periods. Furthermore, the table shows that while changing the number of working hours in the same job is more frequent in small firms, the frequency of such type of mobility has increased relatively more in medium and large sized firms as is shown by the difference-indifferences estimator. This is in accordance with the effect one could expect from the Adjustment of Working Hours Act.

\section{Table 3}

Hours and job mobility patterns of Dutch employees in small sized (less than 10 employees) and medium and large sized firms (10 or more employees), pre and post-Act comparison; difference-indifferences

\begin{tabular}{|c|c|c|c|c|c|c|c|}
\hline & \multicolumn{3}{|c|}{$\begin{array}{c}1994-2000 \\
\text { (pre-Act) }\end{array}$} & \multicolumn{3}{|c|}{$\begin{array}{c}2000-2006 \\
\text { (post-Act) }\end{array}$} & \multirow{2}{*}{$\begin{array}{l}\text { Difference } \\
\text { in- } \\
\text { differences }\end{array}$} \\
\hline & $\begin{array}{l}\text { Firms } 1-9 \\
\text { employees }\end{array}$ & $\begin{array}{l}\text { Firms 10+ } \\
\text { employees }\end{array}$ & Difference & $\begin{array}{l}\text { Firms } 1-9 \\
\text { employees }\end{array}$ & $\begin{array}{l}\text { Firms 10+ } \\
\text { employees }\end{array}$ & Difference & \\
\hline $\begin{array}{l}\text { No job mobility / } \\
\text { no change of } \\
\text { hours }{ }^{1} \text { ) }\end{array}$ & 57.8 & 61.1 & 3.3 & 52.5 & 58.7 & 6.2 & 2.9 \\
\hline $\begin{array}{l}\text { Job mobility / } \\
\text { no change of } \\
\text { hours's) }\end{array}$ & 14.6 & 17.2 & 2.6 & 18.1 & 17.6 & -0.5 & -3.1 \\
\hline $\begin{array}{l}\text { No job mobility / } \\
\text { change of hours }\end{array}$ & 10.9 & 8.6 & -2.3 & 12.6 & 12.1 & -0.5 & 1.8 \\
\hline $\begin{array}{l}\text { Job mobility / } \\
\text { change of hours } \\
\text { Exit from labour }\end{array}$ & 8.4 & 7.9 & -0.5 & 8.4 & 8.2 & -0.3 & 0.2 \\
\hline $\begin{array}{l}\text { market } \\
\text { Total }\end{array}$ & $\begin{array}{c}8.3 \\
(n=835)\end{array}$ & $\begin{array}{c}5.1 \\
(n=4,009)\end{array}$ & -3.1 & $\begin{array}{l}8.4 \\
(n=591)\end{array}$ & $\begin{array}{c}3.5 \\
(n=4,847)\end{array}$ & -5.0 & -1.9 \\
\hline
\end{tabular}

${ }^{1)}$ No change or change is less than 4 hours. 


\subsection{Model estimates}

In Tables 4 and 5, we present the estimates for the multinomial logit model for males and females respectively. Because our main concern here is to test the effect of legislation on hour constraints we only discuss the effects of the relevant variables: firms size and preferences for working hours, and their interaction with time.

After controlling for business cycle effects, the time dummies in the model are indicative for changes in mobility patterns that took place after the introduction of the new Dutch Act for working time adjustments for employees in small firms. ${ }^{8}$ It shows that male employees were more likely to leave the labour force in the period 1986-1994 (Table 4). Male employees in medium or large sized firms are less likely to exit the labour market in the period 2000-2006. Both findings reflect the increase in average retirement age in the Netherlands since the 1990s. Our findings do not suggest that new Dutch Act has had any significant effect upon facilitating hours adjustments within the job for males since the interaction between time and firm size dummies is insignificant in the equation for change of hours without job mobility.

Irrespective of the firm size, female employees are found to be less likely to leave the labour market in the period 2000-2006 compared to the period of reference (Table 5). This reflects the significant increase in labour force participation of females in the Netherlands. Females in medium sized and large firms more likely to display hours and job mobility simultaneously. Such mobility patterns, however, were significantly less frequent in the pre-Act period. With respect to the change of working hours within the same job, we find - as was the case with males - no differences across firm size, nor do we find significant effects for the cross-term with time (except for the time interactions in the period 19861994).

Hence, contrary to the bivariate results in Table 3, once we control for observed characteristics of the employees, we do not find that employees in medium or large firms (where the Act applies) find it easier to change their working hours while remaining in their job than employees in small firms (where the Act does not apply).

8. Sensitivity checks showed that failing to control for the business cycle exaggerates the effect of the time dummies. 
For both males and females, we do find that a preference for a different number of working hours is a strong determinant for a change in actual working hours. This confirms the findings from earlier Dutch research (Euwals et al., 1998; Euwals, 2001). Male employees who are dissatisfied with their actual working hours are significantly more likely to change hours within their current job. The effects for female workers are even more pronounced. Moreover, females who are dissatisfied with their current number of working hours are also more likely to change their working hours and their job simultaneously. Under the assumption that the new Dutch Act has affected mobility patterns, one would expect that dissatisfied workers more often adapt their working hours without changing job in the postAct period. However, the coefficients show no significant period effects for the various mobility patterns neither for male nor for female employees. They are just as likely to change hours and job at the same time after the introduction of the Act as they were prior to the Act. Furthermore, dissatisfied workers are not significantly less likely to withdraw from the labour market in the post-Act period.

\section{Table 4}

Multinomial logit estimates for the probability of job and hours mobility between $t$ and $t+2$, male employees, 1986-2006 (marginal effects)

\begin{tabular}{lcccc}
\hline $\begin{array}{l}\text { Reference: No job mobility/ } \\
\text { change of hours }\end{array}$ & $\begin{array}{c}\text { Job mobility/ } \\
\text { no change of } \\
\text { hours }\end{array}$ & $\begin{array}{c}\text { No job } \\
\text { mobility/ } \\
\text { change of } \\
\text { hours }\end{array}$ & $\begin{array}{c}\text { Job mobility/ } \\
\text { change of } \\
\text { hours }\end{array}$ & $\begin{array}{c}\text { Exit from } \\
\text { labour market }\end{array}$ \\
\hline Time dummies & & & & \\
(ref: 1994-2000) & -0.028 & -0.001 & -0.004 & $0.041^{* *}$ \\
1986-1994 & $(0.031)$ & $(0.012)$ & $(0.009)$ & $(0.020)$ \\
& 0.001 & 0.020 & -0.007 & 0.014 \\
2000-2006 & $(0.040)$ & $(0.016)$ & $(0.010)$ & $(0.020)$ \\
& & & & \\
Firm size (ref: $<$ 10 employees) & -0.026 & -0.003 & -0.003 & -0.012 \\
10-99 employees & $(0.029)$ & $(0.010)$ & $(0.008)$ & $(0.013)$ \\
& -0.000 & 0.003 & -0.006 & $-0.028^{* *}$ \\
>99 employees & $(0.030)$ & $(0.011)$ & $(0.008)$ & $(0.013)$ \\
& 0.062 & 0.012 & 0.010 & -0.014 \\
10-99 employees $\times 1986-1994$ & $(0.046)$ & $(0.020)$ & $(0.016)$ & $(0.009)$ \\
& 0.008 & -0.001 & 0.027 & $-0.020^{* *}$ \\
10-99 employees $\times 2000-2006$ & $(0.044)$ & $(0.013)$ & $(0.029)$ & $(0.008)$ \\
& 0.048 & -0.003 & 0.005 & -0.012 \\
$>99$ employees $\times 1986-1994$ & $(0.045)$ & $(0.012)$ & $(0.014)$ & $(0.012)$ \\
& 0.026 & -0.006 & 0.022 & $-0.018^{*}$ \\
$>99$ employees $\times 2000-2006$ & $(0.047)$ & $(0.010)$ & $(0.026)$ & $(0.010)$ \\
& & & &
\end{tabular}


Table 4 (continued)

Multinomial logit estimates for the probability of job and hours mobility between $t$ and $t+2$, male employees, 1986-2006 (marginal effects)

\begin{tabular}{|c|c|c|c|c|}
\hline $\begin{array}{l}\text { Reference: No job mobility/ } \\
\text { change of hours }\end{array}$ & $\begin{array}{c}\text { Job mobility/ } \\
\text { no change of } \\
\text { hours }\end{array}$ & $\begin{array}{c}\text { No job } \\
\text { mobility/ } \\
\text { change of } \\
\text { hours }\end{array}$ & $\begin{array}{l}\text { Job mobility/ } \\
\text { change of } \\
\text { hours }\end{array}$ & $\begin{array}{c}\text { Exit from } \\
\text { labour market }\end{array}$ \\
\hline Dissatisfied with number of hours & $\begin{array}{l}-0.011 \\
(0.018)\end{array}$ & $\begin{array}{l}0.024^{* *} \\
(0.011)\end{array}$ & $\begin{array}{l}0.012 \\
(0.009)\end{array}$ & $\begin{array}{l}0.016 \\
(0.013)\end{array}$ \\
\hline $\begin{array}{l}\text { Dissatisfied with number of hours } \times \\
\text { 1986-1994 }\end{array}$ & $\begin{array}{c}0.011 \\
(0.025)\end{array}$ & $\begin{array}{c}0.002 \\
(0.009)\end{array}$ & $\begin{array}{l}0.003 \\
(0.009)\end{array}$ & $\begin{array}{l}-0.010 \\
(0.009)\end{array}$ \\
\hline $\begin{array}{l}\text { Dissatisfied with number of hours } \times \\
2000-2006\end{array}$ & $\begin{array}{c}0.045 \\
(0.032)\end{array}$ & $\begin{array}{l}-0.006 \\
(0.007)\end{array}$ & $\begin{array}{c}0.015 \\
(0.014)\end{array}$ & $\begin{array}{l}-0.000 \\
(0.015)\end{array}$ \\
\hline Regional unemployment rate & $\begin{array}{c}0.003 \\
(0.003)\end{array}$ & $\begin{array}{l}-0.003^{* *} \\
(0.001)\end{array}$ & $\begin{array}{l}-0.001 \\
(0.001)\end{array}$ & $\begin{array}{l}-0.001 \\
(0.002)\end{array}$ \\
\hline Age & $\begin{array}{l}-0.009^{* *} \\
(0.005)\end{array}$ & $\begin{array}{l}-0.007^{* * *} \\
(0.002)\end{array}$ & $\begin{array}{l}-0.003^{*} \\
(0.002)\end{array}$ & $\begin{array}{c}0.003 \\
(0.002)\end{array}$ \\
\hline Age squared (/100) & $\begin{array}{c}0.000 \\
(0.006)\end{array}$ & $\begin{array}{l}0.009^{* * *} \\
(0.003)\end{array}$ & $\begin{array}{l}0.003 \\
(0.002)\end{array}$ & $\begin{array}{l}-0.004 \\
(0.003)\end{array}$ \\
\hline \multicolumn{5}{|l|}{$\begin{array}{l}\text { Household type } \\
\text { (ref: couple, no child) }\end{array}$} \\
\hline Couple with child younger than 6 y.o. & $\begin{array}{c}0.001 \\
(0.011)\end{array}$ & $\begin{array}{l}0.001 \\
(0.005)\end{array}$ & $\begin{array}{l}-0.006 \\
(0.004)\end{array}$ & $\begin{array}{l}-0.010 \\
(0.007)\end{array}$ \\
\hline Single & $\begin{array}{l}-0.046^{* * *} \\
(0.016)\end{array}$ & $\begin{array}{l}0.003 \\
(0.006)\end{array}$ & $\begin{array}{l}-0.001 \\
(0.005)\end{array}$ & $\begin{array}{c}0.018 \\
(0.012)\end{array}$ \\
\hline \multicolumn{5}{|l|}{$\begin{array}{l}\text { Educational level } \\
\text { (ref: secondary education) }\end{array}$} \\
\hline Low education & $\begin{array}{l}-0.048^{* * *} \\
(0.011)\end{array}$ & $\begin{array}{c}0.004 \\
(0.004)\end{array}$ & $\begin{array}{l}-0.006 \\
(0.004)\end{array}$ & $\begin{array}{c}0.004 \\
(0.006)\end{array}$ \\
\hline High education/university & $\begin{array}{l}0.030^{* *} \\
(0.014)\end{array}$ & $\begin{array}{l}-0.004 \\
(0.004)\end{array}$ & $\begin{array}{c}0.000 \\
(0.004)\end{array}$ & $\begin{array}{l}-0.005 \\
(0.007)\end{array}$ \\
\hline Number of hours of partner & $\begin{array}{c}0.000 \\
(0.000)\end{array}$ & $\begin{array}{l}-0.000 \\
(0.000)\end{array}$ & $\begin{array}{c}0.000 \\
(0.000)\end{array}$ & $\begin{array}{c}0.000 \\
(0.000)\end{array}$ \\
\hline Hourly wage (log) & $\begin{array}{l}-0.009 \\
(0.017)\end{array}$ & $\begin{array}{l}0.018^{* *} \\
(0.008)\end{array}$ & $\begin{array}{l}-0.004 \\
(0.005)\end{array}$ & $\begin{array}{c}0.010 \\
(0.010)\end{array}$ \\
\hline Part-time job & $\begin{array}{l}-0.110^{* * *} \\
(0.019)\end{array}$ & $\begin{array}{l}0.096^{* * *} \\
(0.026)\end{array}$ & $\begin{array}{l}0.092^{* * *} \\
(0.026)\end{array}$ & $\begin{array}{l}0.049^{* * *} \\
(0.018)\end{array}$ \\
\hline Over time work & $\begin{array}{l}0.038^{* * *} \\
(0.010)\end{array}$ & $\begin{array}{l}-0.003 \\
(0.004)\end{array}$ & $\begin{array}{l}-0.003 \\
(0.003)\end{array}$ & $\begin{array}{l}-0.001 \\
(0.005)\end{array}$ \\
\hline Permanent contract & $\begin{array}{l}-0.082^{* * *} \\
(0.023)\end{array}$ & $\begin{array}{l}-0.007 \\
(0.007)\end{array}$ & $\begin{array}{l}-0.036^{* * *} \\
(0.013)\end{array}$ & $\begin{array}{l}-0.082^{* * *} \\
(0.026)\end{array}$ \\
\hline Managerial job & $\begin{array}{l}0.015^{* * *} \\
(0.004)\end{array}$ & $\begin{array}{l}-0.001 \\
(0.001)\end{array}$ & $\begin{array}{c}0.001 \\
(0.001)\end{array}$ & $\begin{array}{c}0.002 \\
(0.002)\end{array}$ \\
\hline Heavy duty & $\begin{array}{l}-0.004 \\
(0.010)\end{array}$ & $\begin{array}{c}0.002 \\
(0.004)\end{array}$ & $\begin{array}{c}0.003 \\
(0.004)\end{array}$ & $\begin{array}{c}0.000 \\
(0.005)\end{array}$ \\
\hline Dissatisfied with job & $\begin{array}{l}0.096^{* * *} \\
(0.020)\end{array}$ & $\begin{array}{c}0.002 \\
(0.006)\end{array}$ & $\begin{array}{l}0.016^{* *} \\
(0.007)\end{array}$ & $\begin{array}{l}0.057^{* * *} \\
(0.019)\end{array}$ \\
\hline Sector (ref: industry and energy) & & & & \\
\hline Agriculture & $\begin{array}{l}-0.039 \\
(0.031)\end{array}$ & $\begin{array}{c}0.027 \\
(0.022)\end{array}$ & $\begin{array}{c}0.010 \\
(0.014)\end{array}$ & $\begin{array}{l}-0.009 \\
(0.017)\end{array}$ \\
\hline
\end{tabular}


Table 4 (continued)

Multinomial logit estimates for the probability of job and hours mobility between $t$ and $t+2$, male employees, 1986-2006 (marginal effects)

\begin{tabular}{|c|c|c|c|c|}
\hline $\begin{array}{l}\text { Reference: No job mobility/ } \\
\text { change of hours }\end{array}$ & $\begin{array}{l}\text { Job mobility/ } \\
\text { no change of } \\
\text { hours }\end{array}$ & $\begin{array}{c}\text { No job } \\
\text { mobility/ } \\
\text { change of } \\
\text { hours }\end{array}$ & $\begin{array}{l}\text { Job mobility/ } \\
\text { change of } \\
\text { hours }\end{array}$ & $\begin{array}{c}\text { Exit from } \\
\text { labour market }\end{array}$ \\
\hline \multirow[t]{2}{*}{ Construction } & -0.016 & $0.022^{* *}$ & $-0.011^{* *}$ & 0.015 \\
\hline & $(0.017)$ & $(0.011)$ & $(0.006)$ & $(0.012)$ \\
\hline \multirow[t]{2}{*}{ Commerce and catering } & 0.014 & 0.009 & -0.006 & -0.000 \\
\hline & $(0.016)$ & $(0.008)$ & $(0.005)$ & $(0.008)$ \\
\hline \multirow[t]{2}{*}{ Transport } & 0.009 & 0.001 & -0.007 & -0.012 \\
\hline & $(0.018)$ & $(0.008)$ & $(0.005)$ & $(0.009)$ \\
\hline \multirow[t]{2}{*}{ Financial business services } & 0.025 & 0.008 & -0.002 & 0.007 \\
\hline & $(0.017)$ & $(0.007)$ & $(0.005)$ & $(0.009)$ \\
\hline \multirow[t]{2}{*}{ Other services } & -0.015 & 0.019 & 0.013 & 0.002 \\
\hline & $(0.025)$ & $(0.014)$ & $(0.011)$ & $(0.013)$ \\
\hline \multirow[t]{2}{*}{ Public sector } & $0.039 * *$ & -0.000 & -0.000 & $-0.019 * *$ \\
\hline & $(0.018)$ & $(0.006)$ & $(0.006)$ & $(0.009)$ \\
\hline \multirow[t]{2}{*}{ Education } & $-0.086^{* * *}$ & $0.078^{* * *}$ & $0.018^{*}$ & -0.015 \\
\hline & $(0.021)$ & $(0.025)$ & $(0.010)$ & $(0.010)$ \\
\hline \multirow[t]{2}{*}{ Healthcare } & -0.016 & 0.006 & $0.020^{*}$ & -0.011 \\
\hline & $(0.020)$ & $(0.009)$ & $(0.011)$ & $(0.011)$ \\
\hline Pseudo-R-square & 0.098 & & & \\
\hline Chi-square & 1752.437 & & & \\
\hline df & 140 & & & \\
\hline Loglikelihood & -8361.792 & & & \\
\hline $\mathrm{N}$ (person-time) & 9033 & & & \\
\hline Number of individuals & 3794 & & & \\
\hline
\end{tabular}

\section{Table 5}

Multinomial logit estimates for the probability of job and hours mobility between $t$ and $t+2$, female employees, 1986-2006 (marginal effects)

\begin{tabular}{lcccc}
\hline Reference: & $\begin{array}{c}\text { Job mobility/ } \\
\text { No job mobility/change of hours } \\
\text { hours }\end{array}$ & $\begin{array}{c}\text { No job } \\
\text { mobility/ } \\
\text { change of } \\
\text { hours }\end{array}$ & $\begin{array}{c}\text { Job mobility/ } \\
\text { change of } \\
\text { hours }\end{array}$ & $\begin{array}{c}\text { Exit from } \\
\text { labour market }\end{array}$ \\
\hline Time dummies (ref: 1994-2000) & 0.011 & 0.006 & 0.031 & $0.044^{*}$ \\
$1986-1994$ & $(0.029)$ & $(0.028)$ & $(0.022)$ & $(0.025)$ \\
2000-2006 & 0.059 & -0.001 & 0.002 & $-0.043^{*}$ \\
Firm size (ref: < 10 employees) & $(0.036)$ & $(0.029)$ & $(0.022)$ & $(0.023)$ \\
10-99 employees & -0.028 & 0.030 & $0.043^{* *}$ & $-0.034^{*}$ \\
& $(0.024)$ & $(0.022)$ & $(0.018)$ & $(0.019)$
\end{tabular}


Table 5 (continued)

Multinomial logit estimates for the probability of job and hours mobility between $t$ and $t+2$, female employees, 1986-2006 (marginal effects)

\begin{tabular}{|c|c|c|c|c|}
\hline $\begin{array}{l}\text { Reference: } \\
\text { No job mobility/change of hours }\end{array}$ & $\begin{array}{l}\text { Job mobility/ } \\
\text { no change of } \\
\text { hours }\end{array}$ & $\begin{array}{c}\text { No job } \\
\text { mobility/ } \\
\text { change of } \\
\text { hours }\end{array}$ & $\begin{array}{c}\text { Job mobility/ } \\
\text { change of } \\
\text { hours }\end{array}$ & $\begin{array}{c}\text { Exit from } \\
\text { labour market }\end{array}$ \\
\hline \multirow[t]{2}{*}{$>99$ employees } & 0.005 & 0.002 & $0.030^{*}$ & $-0.033^{*}$ \\
\hline & $(0.024)$ & $(0.023)$ & $(0.017)$ & $(0.019)$ \\
\hline \multirow[t]{2}{*}{ 10-99 employees $\times 1986-1994$} & 0.004 & -0.026 & $-0.030 * * *$ & -0.000 \\
\hline & $(0.034)$ & $(0.021)$ & $(0.010)$ & $(0.026)$ \\
\hline \multirow[t]{2}{*}{ 10-99 employees $\times$ 2000-2006 } & -0.021 & -0.001 & -0.022 & 0.026 \\
\hline & $(0.029)$ & $(0.029)$ & $(0.014)$ & $(0.043)$ \\
\hline \multirow[t]{2}{*}{ > 99 employees × 1986-1994 } & -0.009 & $-0.040^{* *}$ & $-0.026^{* *}$ & -0.022 \\
\hline & $(0.029)$ & $(0.017)$ & $(0.011)$ & $(0.018)$ \\
\hline \multirow[t]{2}{*}{ > 99 employees $\times$ 2000-2006 } & -0.012 & 0.012 & -0.010 & 0.010 \\
\hline & $(0.030)$ & $(0.034)$ & $(0.019)$ & $(0.036)$ \\
\hline \multirow[t]{2}{*}{ Dissatisfied with number of hours } & -0.020 & $0.069 * * *$ & $0.089 * * *$ & 0.023 \\
\hline & $(0.018)$ & $(0.019)$ & $(0.019)$ & $(0.018)$ \\
\hline Dissatisfied with number of hours $\times$ & -0.006 & -0.006 & -0.008 & -0.008 \\
\hline 1986-1994 & $(0.024)$ & $(0.020)$ & $(0.012)$ & $(0.019)$ \\
\hline Dissatisfied with number of hours $x$ & -0.008 & 0.001 & -0.016 & 0.018 \\
\hline $2000-2006$ & $(0.025)$ & $(0.020)$ & $(0.012)$ & $(0.031)$ \\
\hline \multirow[t]{2}{*}{ Regional unemployment rate } & 0.003 & -0.003 & $-0.008^{* * *}$ & -0.001 \\
\hline & $(0.003)$ & $(0.003)$ & $(0.003)$ & $(0.003)$ \\
\hline \multirow[t]{2}{*}{ Age } & 0.002 & 0.000 & 0.004 & 0.002 \\
\hline & $(0.004)$ & $(0.004)$ & $(0.003)$ & $(0.004)$ \\
\hline \multirow[t]{2}{*}{ Age squared (/100) } & -0.005 & -0.001 & $-0.010^{* *}$ & -0.005 \\
\hline & $(0.006)$ & $(0.005)$ & $(0.004)$ & $(0.005)$ \\
\hline \multicolumn{5}{|l|}{ Household type } \\
\hline \multicolumn{5}{|l|}{ (ref: couple, no child) } \\
\hline \multirow[t]{2}{*}{ Couple with child younger than 6 y.o. } & $-0.030^{* *}$ & $-0.026^{* *}$ & -0.010 & 0.015 \\
\hline & $(0.014)$ & $(0.011)$ & $(0.008)$ & $(0.013)$ \\
\hline \multirow[t]{2}{*}{ Single } & $0.033^{*}$ & $-0.028^{* *}$ & 0.004 & $-0.029^{*}$ \\
\hline & $(0.017)$ & $(0.014)$ & $(0.011)$ & $(0.015)$ \\
\hline \multicolumn{5}{|l|}{ Educational level } \\
\hline \multicolumn{5}{|l|}{ (ref: secondary education) } \\
\hline \multirow[t]{2}{*}{ Low education } & $-0.040^{* * *}$ & 0.007 & 0.006 & $0.034^{* * *}$ \\
\hline & $(0.012)$ & $(0.010)$ & $(0.008)$ & $(0.013)$ \\
\hline \multirow[t]{2}{*}{ High education/university } & 0.007 & $0.022^{*}$ & $0.019^{* *}$ & 0.012 \\
\hline & $(0.013)$ & $(0.012)$ & $(0.009)$ & $(0.014)$ \\
\hline
\end{tabular}


Table 5 (continued)

Multinomial logit estimates for the probability of job and hours mobility between $t$ and $t+2$, female employees, 1986-2006 (marginal effects)

\begin{tabular}{|c|c|c|c|c|}
\hline $\begin{array}{l}\text { Reference: } \\
\text { No job mobility/change of hours }\end{array}$ & $\begin{array}{c}\text { Job mobility/ } \\
\text { no change of } \\
\text { hours }\end{array}$ & $\begin{array}{c}\text { No job } \\
\text { mobility/ } \\
\text { change of } \\
\text { hours }\end{array}$ & $\begin{array}{c}\text { Job mobility/ } \\
\text { change of } \\
\text { hours }\end{array}$ & $\begin{array}{c}\text { Exit from } \\
\text { labour market }\end{array}$ \\
\hline \multirow[t]{2}{*}{ Number of hours of partner } & -0.000 & -0.000 & -0.000 & -0.000 \\
\hline & $(0.000)$ & $(0.000)$ & $(0.000)$ & $(0.000)$ \\
\hline \multirow[t]{2}{*}{ Hourly wage (log) } & $-0.029^{*}$ & 0.001 & $-0.018^{* *}$ & -0.018 \\
\hline & $(0.015)$ & $(0.015)$ & $(0.009)$ & $(0.014)$ \\
\hline \multirow[t]{2}{*}{ Part-time job } & $-0.060^{* * *}$ & $0.024^{* *}$ & $0.041^{* * *}$ & $0.036^{* * *}$ \\
\hline & $(0.015)$ & $(0.011)$ & $(0.010)$ & $(0.012)$ \\
\hline \multirow[t]{2}{*}{ Over time work } & 0.016 & -0.010 & 0.009 & -0.016 \\
\hline & $(0.011)$ & $(0.009)$ & $(0.007)$ & $(0.010)$ \\
\hline \multirow[t]{2}{*}{ Permanent contract } & $-0.039 * *$ & -0.018 & $-0.065^{* * *}$ & $-0.117^{* * *}$ \\
\hline & $(0.017)$ & $(0.013)$ & $(0.016)$ & $(0.025)$ \\
\hline \multirow[t]{2}{*}{ Managerial job } & $0.013^{* *}$ & -0.004 & 0.003 & -0.004 \\
\hline & $(0.005)$ & $(0.005)$ & $(0.004)$ & $(0.006)$ \\
\hline \multirow[t]{2}{*}{ Heavy duty } & -0.010 & -0.009 & $-0.011^{*}$ & $0.038^{* * *}$ \\
\hline & $(0.010)$ & $(0.008)$ & $(0.006)$ & $(0.013)$ \\
\hline \multirow[t]{2}{*}{ Dissatisfied with job } & $0.076^{* * *}$ & -0.023 & $0.056^{* * *}$ & $0.088^{* * *}$ \\
\hline & $(0.022)$ & $(0.014)$ & $(0.016)$ & $(0.023)$ \\
\hline \multicolumn{5}{|l|}{ Sector (ref: industry and energy) } \\
\hline \multirow[t]{2}{*}{ Agriculture } & $-0.082^{* *}$ & 0.010 & -0.007 & 0.044 \\
\hline & $(0.041)$ & $(0.055)$ & $(0.038)$ & $(0.054)$ \\
\hline \multirow[t]{2}{*}{ Construction } & -0.030 & $0.108^{*}$ & 0.051 & 0.050 \\
\hline & $(0.039)$ & $(0.062)$ & $(0.034)$ & $(0.045)$ \\
\hline \multirow[t]{2}{*}{ Commerce and catering } & -0.013 & $0.057^{* *}$ & -0.002 & -0.023 \\
\hline & $(0.021)$ & $(0.028)$ & $(0.013)$ & $(0.015)$ \\
\hline \multirow[t]{2}{*}{ Transport } & 0.028 & 0.019 & -0.011 & -0.029 \\
\hline & $(0.032)$ & $(0.031)$ & $(0.016)$ & $(0.020)$ \\
\hline \multirow[t]{2}{*}{ Financial business services } & 0.032 & -0.013 & 0.004 & -0.018 \\
\hline & $(0.025)$ & $(0.021)$ & $(0.014)$ & $(0.016)$ \\
\hline \multirow[t]{2}{*}{ Other services } & -0.004 & $0.052^{*}$ & 0.014 & -0.013 \\
\hline & $(0.026)$ & $(0.031)$ & $(0.018)$ & $(0.018)$ \\
\hline \multirow[t]{2}{*}{ Public sector } & 0.033 & 0.007 & -0.001 & $-0.031^{*}$ \\
\hline & $(0.027)$ & $(0.025)$ & $(0.015)$ & $(0.017)$ \\
\hline \multirow[t]{2}{*}{ Education } & -0.010 & $0.061^{* *}$ & -0.002 & $-0.049 * * *$ \\
\hline & $(0.024)$ & $(0.031)$ & $(0.015)$ & $(0.017)$ \\
\hline \multirow[t]{2}{*}{ Healthcare } & -0.015 & $0.040^{*}$ & 0.005 & $-0.039 * *$ \\
\hline & $(0.020)$ & $(0.023)$ & $(0.013)$ & $(0.016)$ \\
\hline
\end{tabular}


Table 5 (continued)

Multinomial logit estimates for the probability of job and hours mobility between $t$ and $t+2$, female employees, 1986-2006 (marginal effects)

\begin{tabular}{|c|c|c|c|c|}
\hline $\begin{array}{l}\text { Reference: } \\
\text { No job mobility/change of hours }\end{array}$ & $\begin{array}{c}\text { Job mobility/ } \\
\text { no change of } \\
\text { hours }\end{array}$ & $\begin{array}{c}\text { No job } \\
\text { mobility/ } \\
\text { change of } \\
\text { hours }\end{array}$ & $\begin{array}{c}\text { Job mobility/ } \\
\text { change of } \\
\text { hours }\end{array}$ & $\begin{array}{c}\text { Exit from } \\
\text { labour market }\end{array}$ \\
\hline Pseudo-R-square & 0.072 & & & \\
\hline Chi-square & 1054.396 & & & \\
\hline$d f$ & 140 & & & \\
\hline Loglikelihood & -7788.988 & & & \\
\hline $\mathrm{N}$ (person-time) & 6095 & & & \\
\hline Number of individuals & 2902 & & & \\
\hline
\end{tabular}

Standard errors corrected for intragroup correlation in parentheses.

*** significant at $1 \%,{ }^{* *}$ significant at $5 \%,{ }^{*}$ significant at $10 \%$.

\subsection{Robustness checks}

Having found no significant effects of the new Dutch legislation, it is important to investigate how sensitive our findings are to the choices made in our models. ${ }^{9} \mathrm{~A}$ first issue is that while the law only applies to employees with a tenure of more than one year, we tested its effects on all employees irrespective of the tenure length. However, restricting our sample to employees who have been with their current employer for more than twelve months does not change our results.

A second potential problem is that in our analyses we have not made the distinction between job mobility with another employer and job mobility within the same firm. This could potentially bias our difference-in-differences estimator, both because the law applies to within firm hours changes and because the opportunities for within firm mobility are greater in large firms than in small firms. Restricting our measure of mobility to capture only changes of employer does not lead us to reach other conclusions with respect to the effects of the legislation. Male and female workers in lager firms (compared to small firms) do not find it easier to change their hours within the same firm after the legislation came into force. Neither are they less likely to change hours and job simultaneously in the post

9. Since we do find any effect of the law we do not need to worry about possible underestimation of the standard error of our difference-in-differences estimator (Bertand et al., 2004). 
legislation period. The effect of the dissatisfaction with the working hours is also not different in the pre and post legislation period.

A third potential issue is that while the legislation does apply to any change in the labour supply (either more or fewer hours), its effect could well be different for employees wanting to increase their labour supply compared to employees wanting to reduce it. If this is indeed the case, our analyses would fail to pick up this differential effect. We estimated two additional models: the first model focuses on the likelihood to increase the number of hours worked, while the second focuses on reduction of the number of hours worked. Our main findings remain the same for both males and females in the model where we restrict our measure of mobility to only account for increases in the labour supply. For male workers the differencein-differences estimator does not change either when our measure of mobility only accounts for a reduction in the labour supply. For female workers in medium-sized firms, we do find that they are significantly less likely to reduce their number of working hours in conjunction with job mobility in the post-Act period compared to workers in small firms. However, this finding also holds for the pre-Act period (1986-1994). Henceforth, this change in mobility pattern cannot directly be linked to the new Act.

A fourth potential issue is that unobserved individual characteristics could affect our findings. Correcting for unobserved heterogeneities could be of importance because one could argue that the intrinsic characteristics and motivations of workers who display the various types of mobility are different. For example, one could contend that workers who manage to change their hours without displaying job mobility are more assertive or are more skillful in negotiating with their employer. Elsewhere, we estimated a panel multinomial logit models on the data for the period 1986-2002 and we showed that unobserved heterogeneity only affects the mobility pattern of males in the job mobility/no change of hours equation and the mobility pattern of female in the job mobility/change of hours equation (Fouarge and Baaijens, 2004). Moreover, correcting for unobserved characteristics does not affect our findings.

Finally, in our study, the period following the introduction of the new Adjustment of Working Hours Act amounts to six years. However, it is possible that such a law has a one-off effect with the stock of employees unhappy about their number of hours take the opportunity of changing their labour supply shortly 
after the introduction of the law. Although we expect this behaviour to show in our findings, we replicated our analysis while restricting the post-Act period to the two and four years following the new law. None of these restrictions changed our findings.

\section{Discussion}

A large body of literature shows that changes in working hours often coincide with job mobility. This means that labour demand constraints affect the probability of adjusting the number of working hours. With the introduction of the Adjustment of Working Hours Act in 2000 - the Act gives a formal right to employees to adapt the length of their working week within their current job - Dutch policy makers expected to smooth away such labour demand constraints. Such institutions aiming at facilitating working time transitions have received a great deal of attention lately (see, for example, O’Reilly, 2003).

With the new Act we expected adjustments of working hours to be less often realized by means of job mobility. Descriptive findings indicate that changes of hours within the job indeed appear to have increased. However, using employees in small firms as a control group - the Act does not apply to small firms - and applying a difference-in-differences methodology, our econometric model suggests no such effect. Employees in large firms (whether male or female) do not find it easier to change their working hours while remaining in their job in the post-Act period. Likewise, for male and female workers who are dissatisfied with their number of working hours - the target group of this new Act - we found no significant effect of the legislation. They are equally likely to change hours and job or to exit the labour market and, more importantly, no more likely to change hours without changing job after the introduction of the Act than prior to the Act. This finding is not sensitive to key modelling choices made for our analysis. In particular, whether we consider increases or decreases in the number of working hours, no effect is found.

Although the Dutch labour market, with its large part-time segment, is a particular one, it does not stand alone in Europe. Germany, the UK, Sweden and Denmark, for example, also have a large proportion of part-time employment. 
Despite this apparent working time flexibility, hours changes within the job still seem to be difficult in the Netherlands, and the recently introduced Adjustment of Working Hours Act has not changed this situation. In Germany where a similar law - the Act on Part-time Work and Fixed-term Contracts - was introduced in 2001, the relation between working time reduction and job mobility has not changed either (Munz, 2004).

What lessons can be learned from the Dutch experience? It is possible that the positive effects of such policy measures will only become apparent in the longer run. It could be that the new legislation will induce a further 'normalisation' of part-time employment, and more transitions between full-time and part-time jobs during the course of the working life. However, it is difficult to evaluate such longterm effects because it can also come from other sorts of contextual changes that one cannot control for. For example, in the longer run, employers could change their production technology in order to allow for greater flexibility.

Previous research has shown that many employees with a desire to adjust working hours are reluctant to put forward such requests. Employees (especially male employees) see their employer and the nature of their job as important obstacles in realising a preference for working a different number of hours. They seem to fear that their employer will not approve or to think that it is not possible in their job, although this may not objectively be the case. Furthermore, requests that have been put forward, seem to be reasonably successful. This indicates also that before the introduction of the Adjustment of Working Hours Act many employees succeeded in adjusting working hours.

Over the years, employers in the Netherlands have understood the advantages of part-time employment as a form of flexible labour, and as a way of increasing labour supply in a situation of shortages in the labour market. Nevertheless, both employer and employee behaviour are likely to be different in the various phases of the business cycle, which might explain why the new Act has had no measurable effect. When the labour market is tight, an employer will be more willing to grant an employee's request for a change in working hours rather than see him or her leave the firm for another job with the preferred number of working hours. Under these conditions employers and employees will often manage to work out a solution that benefits both, and there is no need for legislation. In economic downturn, employers would be happy to decrease the 
number of working hours of employees. However, employees can be expected to be reluctant addressing issues of adjustments of working hours: on the one hand, there is little scope for increases in working hours and, on the other hand, requesting a reduction in working hours would be issuing a wrong signal to one's employer.

Nevertheless, although we find no measurable effect of the Dutch Act this does not make it a useless instrument. Even though some employees manage quite well with their employer in setting the working hours in accordance to their preferences and family needs, those working for profit-maximizing employers who are unwilling to change the labour contract because this flexibility in the working hours does not benefit them might be less lucky. For them, the legislation might prove to be useful. In this sense the Adjustment of Working Hours Act could function as 'the big stick' for employers and employees to solve problems around adjustment of working hours in a way that is satisfying for all parties. After all, employers know that if they react in an unreasonable way to any request for adjustment of working hours, employees can take the matter to court. At the same time, neither party has an interest in letting it come that far, for in general, a lawsuit disrupts the relationship between employer and employee severely.

\section{References}

Altonji, J. and Paxson, C., 1986. Job characteristics and hours of work, in R.G. Ehrenberg, ed., Research in Labor Economics (Westview Press, Greenwich) 155 .

Altonji, J. and Paxson, C., 1988. Labor supply preferences, hours constraints and hours-wage trade-offs. Journal of Labor Economics 6, 254-276.

Altonji, J. and Paxson, C., 1992. Labor supply, hours constraints and job mobility. The Journal of Human Resources 27, 256-278.

Beckers, I. and van der Valk, J., 2005. Meer of minder willen werken. Sociaaleconomische Trends 2005-1, 10-13. 
Bertrand, M., Duflo, E. and Mullainathan, S., 2004. How much should we trust differences-in-differences estimates? Quarterly Journal of Economics 119: 249275 .

Bielenski, H., Bosch, G. and Wagner, A., 2002. Working time preferences in sixteen European countries (European Foundation for the improvement of Living and Working Conditions, Dublin).

Böheim, R. and Taylor, M., 2004. Actual and preferred working hours. British Journal of Industrial Relations 42, 149-166.

Burri, S., Opitz H. and Veldman, A., 2003. Work-family policies on working time put into practice. A comparison of Dutch and German case law on working time adjustment. The International Journal of Comparative Labour Law and Industrial Relations 19, 321-46.

Camonier, A., 2003. Wet aanpassing arbeidsduur; bodemprocedure of kort geding, Arbeid Integraal 2, april 2003, 55-57.

Delsen, L., Bosworth, D., Gross, H. and Munoz de Bustillo y Llorente, R., 2007. Operating hours and working times: a survey of capacity utilisation and employment in the European Union (Physica, Heidelberg).

Dex, S. and Joshi, H., 1999. Careers and motherhood: policies for compatibility, Cambridge Journal of Economics, vol. 23, 641-659.

EIRO, 2003. New Rules on Flexible Working Come into Force (UK) (http://www.eiro.eurofound.eu.int).

Euwals, R., 2001. Female labour supply, flexibility of working hours, and job mobility. The Economic Journal 111, c120-c134.

Euwals, R., Melenberg, B. and van Soest, A., 1998. Testing the predictive value of subjective labour supply data. Journal of Applied Econometrics 13, 567-585. 
Fouarge, D. and Baaijens, C., 2004. 'Changes of working hours and job mobility: the effect of Dutch legislation'. OSA Working Paper 2004-23, Tilburg.

Fouarge, D. and Baaijens, C., 2006. Labour supply preferences and job mobility of Dutch employees. In: Messenger, J., J-Y. Boulin, M. Lallement, and F. Michon (eds.). Decent working time: new trends new issues. Geneva: ILO (pp. 155-179)

Fouarge, D. and Muffels, R., 2009. Working part-time in The British, German and Dutch Labour Market: Scarring for the Wage Career? Journal of Applied Social Science Studies, forthcoming.

Freeman, R. and Schettkat, R., 2005. Marketization of household production and the EU-US gap in work. Economic Policy 20, 6-50.

Gielen, A., 2009. Working hours flexibility and older workers' labor supply, Oxford Economic Papers, forthcoming.

Jacobs, A. and Schmidt, M., 2001. The right to part-time work: the Netherlands and Germany compared. The International Journal of Comparative Labour Law and Industrial Relations 17, 371-384.

Kahn, S. and Lang, K., 1992. Constraints in the choice of work hours: agency versus specific capital. The Journal of Human Resources 27, 661-678.

Landers, R., Rebitzer, J. and Taylor, L., 1996. Rat race redux: adverse selection in the determinants of work hours in law firms. The American Economic Review 86, 329-348.

Martinez-Granado, M., 2005. Testing labour supply and hours constraints. Labour Economics 12, 321-343.

Munz, S., 2004. Flexibility of working hours and job mobility in Germany: the role of the part-time and fixed-term act (Ifo, Munich). 
Portegijs, W. and Keuzenkamp, S. 2008. Nederland deeltijdland. Vrouwen en deeltijdwerk [Parttime working in the Netherlands]. The Hagues: SCPpublication 2008/4

O’Reilly, J., 2003. Regulating working time transitions in Europe (Edward Elgar, Chelterham).

Schmidt, M., 2001. The right to part-time work under the German law. Industrial Law Journal 30, 335-351.

Veldman, A., 2003. De WAA als instrument voor het combineren van arbeid en zorg. Een voortgangsrapportage op grond van jurisprudentieonderzoek, Nemesis vol. 19, 28-32.

Visser, J., 2002. The first part-time economy in the world: a model to be followed? Journal of European Social Policy 12: 23-42. 